\title{
RECORDS MANAGEMENT PRACTICES IN GHANAIAN TERTIARY INSTITUTIONS: A CASE STUDY OF GHANA COMMUNICATION TECHNOLOGY UNIVERSITY
}

\author{
${ }^{1 * A m e y a w, ~ S ., ~}{ }^{2}$ Frempong-Kore, A. \\ ${ }^{1}$ Walton Whaley Library, Valley View University, Oyibi - Accra, Ghana \\ ${ }^{2}$ Ghana Communication Technology University Library, Tesano - Accra, Ghana \\ *Corresponding Author's Email: sameyaw@vvu.edu.gh
}

\begin{abstract}
This study was conducted to ascertain records management practices at the Ghana Communication Technology University (formerly Ghana Technology University College) a mid-sized Ghanaian public university located in Accra. All the staff at the Admissions and Records departments participated in the study. This comprised two (2) heads of department and seven (7) senior staff from both departments. The face-to-face interviews were employed as a data collection instrument for this study. The findings indicated that the University has neither a policy to regulate the management of students' records nor a professional archivist to manage records. However, the head of the Records office was given a three-day training on the assumption of office. It was revealed that the head of admissions, as well as all the staff of the two departments, had never been given any training. There were some challenges impeding records management in the Admissions and Records offices-among them are; lack of adequate staff, inadequate storage equipment, lack of periodic training, lack of policy to guide records management and inability of students to furnish the Admission office with the needed information. It was recommended that the University should employ a professional archivist to manage student records, provide adequate storage facilities, organise periodic training for staff as well promulgate a policy to guide records management in the Admissions and Records offices.
\end{abstract}

\section{Keywords: Accra Campus, Records, Management, Practices, Ghana Communication Technology}

\section{University}

\section{Introduction}

The development of academic institutions and the rise of students' enrolment has led to the increasing volumes of students' records, be it paper-based or in electronic format. This phenomenon of everincreasing enrolment of students has called for proper management of records in academic institutions to ensure the safety of records and the quick retrieval of information. Ololube (2013 p. 103) stated that "the importance of good record keeping transcends into short- and long-term benefits, and affects the overall achievement of educational objectives".
Ololube (2013) pointed out some key reasons for records keeping in academic institutions as: Accountability, Decision making, Employment, Guidance Counsellors, Information Bank: Information for Parents, Institutional Planning, Student academic achievement and Behaviour, Subject Time Table and Supervisors /Inspectors. Adu-Oppong and Asante (2014) contend that a proper records administration system guarantees that an institution meets its records keeping requirements by ensuring that it captures 
and preserves the evidence required to

establish its activities and existence.

The importance of students' records management in an academic institution is to help the management of the institution to make informed and effective decisions. It also helps them to design relevant policies that will help the growth of the institution. Students' records in tertiary institutions refer to processed data or information relating to particular students whether in a paper or electronic format that offers evidence to the institution about transactions or activities that had occurred between the institution and the students. Any academic institution that fails to attach importance to proper records management would not succeed in its operations since records are needed for daily business transactions. In every academic institution, whether public or private, records management plays a crucial role since they provide evidence of students' registration, admission, proof of attendance, proof of fees paid, deferment of an academic programme, completion of courses, and withdrawal of students through deviant behaviour. Every academic institution needs to have a proper records management system to ensure that records are kept in good condition to be produced when required.

\section{Statement of the Problem}

The introduction of additional academic programmes at the Ghana Communication Technology University (GCTU), coupled with the rapid growth of students' population, has increased students' records at the Admissions and Records offices. It is an undeniable fact that records are exceptionally important in the management of academic institutions like GCTU. There are some institutions in Ghana that have deficiencies in their records management system, and the majority of vital records are gravely scattered and stored in poor conditions making it difficult for retrieval. GCTU is not an exception to this. Azameti and Adjei (2014a) indicated that the absence of national policy directives for internal records management at different higher education institutions in Ghana pose a challenge to the records management system. A poor records management system impedes the smooth operations of the institution as well as the activities of staff and students' who frequently need these records. A review of literature established that there are no similar studies on deficiencies in student's records management practices in GCTU. Literature has shown again that earlier studies by Atulomah (2011) concentrated on perceived records management practice and decision making among university administrators in Nigeria, whereas Ololube (2013) dwelled on educational management, planning and supervision: model for effective implementation. Similarly, Ifedili and Agbaire (2011) took a study on management of educational records in Nigerian Universities for better results, and in Ghana, Azameti and Adjei (2014) focused on conceptualization of policy challenges in academic records management strategies in tertiary institutions in Ghana, while Mensah and Adams (2014) did a study on the nexus between corporate governance and records management in private and public hospitals in Ghana. Another study was also done by Otu et al. (2014) on management of students' records at Koforidua Polytechnic: Implications for good governance. Preliminary investigations by the researchers revealed that in every graduation period, some students are not able to graduate because of missing records, inability of staff to determine the number of students in good standing academically and difficulty in retrieving records from where they were filed. Interestingly, none of these previous studies focused on records management practices in GCTU. It is against this background that the study was carried out to find out records management practice in GCTU and fill the gap and also make recommendations to the university management.

\section{Objectives}

1. To find out the level of staff knowledge in records management at the Admissions and Records offices of GCTU. 
2. To examine whether the staff of GCTU have training on records management.

3. To find out whether Admissions and Records offices of GCTU have policies on records management.

4. To find out the challenges facing the Admissions and Records offices in managing students' records.

\section{Literature Review}

\section{Knowledge of Staff in Records Management}

"Knowledge is power", so goes the adage. Knowledge in every aspect of human activities supports the day-to-day operations of an institution to fulfil a specific task or reach particular goals of that institution. The level of staff knowledge in records management helps staff to prevent making the same mistakes or prevent staff from reinventing the wheel. Manyambula (2009) opines that one of the factors which has contributed to poor students' records management in some universities is unqualified staff in most Registries, and people who do not have the basic training or without training in records management managing records. Gama (2010) indicated that the lack of sufficient knowledge to manage records effectively and the absence of records management policies were some of the significant challenges hindering effective management of documents in some educational institutions in Nigeria. Egwuyenga (2005) reported that appropriate records keeping by administrators are constrained due to inadequate skills of staff, absence of infrastructure, lack of storage facilities, lack of supervision, and poor records management programme in Nigerian Universities. Iwhiwhu (2005) conducted a study in Nigerian universities and disclosed that the majority of the institutions lack proper records management or archival facilities. The study added that the day-to-day activities were done by clerical /administrative staff who had no idea about what records management was.

\section{Staff training in Students' Records Management}

Training and development are some of the critical components that facilitate the successful growth of an institution. It prepares staff for the present and future development of the institution and also enhances staff to execute their routine operations without many difficulties and frustrations. The acquisition of training in records management in an academic institution can be measured to understand the effect that the training has on staff output. Adequate training also serves as a catalyst that prepares the grounds for staff reward in anticipation of growth in their performance.

Tsabedze et al. (2012) conducted a study on records management in the Government of Swaziland and revealed that staff appointed to the position of Records or Registry Officers were not fully trained in records management. According to the study, majority of the staff obtained Ordinary level certificates, however, none of them had formal training, at least at the Diploma level in records management. Abdulrahman (2015) did a study on management of university records for effective administration of universities in North Central Nigeria. The study established that staff involved in management of records in the university libraries in North Central Nigeria did not have any kind of training.

\section{Policy on Records Management in Academic Institutions}

Records management policy is a well-organised written document that guides the establishment of a records programme. Records management policy should be comprehensive to cover both paper-based and electronic information. The policy should cover the creation and management of authentic, reliable and useable records capable of supporting business functions and activities. The policy should be "adopted and endorsed at the highest decisionmaking level and promulgated throughout the organisation (ISO 15489-1, 2001, clause 6.2)". Dikopoulous and Mihiotis (2012) established that the majority of institutions in Sub-Saharan Africa 
lack written and approved policies for records management which do not augur well for the institutions and their operations. Tagbotor et al. (2015a) analysed records management and organisational performance in a polytechnic in Nigeria and reported that there is a comprehensive records management policies and manual in place which are being used.

The studies of Azameti and Adjei (2013b) added that the state of records management in Ghanaian academic institutions in the past decades was not pleasant. According to the authors, there was a lack of national policy on educational records management and that every single institution had its unique records management system, however, such systems were not without challenges.

The study by Otu et al. (2014) established that the Koforidua Polytechnic had no laid down records management policy and had a weak programme structure for managing records. According to the study, this challenge is due to the absence of a national policy for academic records management which has led to different institutions implementing distinctive policies for educational records management. Similarly, Mensah and Adams (2014) emphasised that the existence of proper records management policies in an institution offers the mandate and general authority for the creation and use, as well as, preservation of records which are crucial to the effective management of every document. Azameti and Adjei (2014) did a study on conceptualization of policy challenges in academic records management strategies in tertiary institutions in Ghana. The finding revealed policy lapses in the management of academic records in most of the high educational institutions in Ghana. The problems originated due to the absence of national policy directives for internal record management policies in different high educational institutions in Ghana. They stressed that the policy challenge in one institution might not differ from what happens in other institutions. The major reason for having record management policies is to guarantee that government agencies capture, preserve and secure a corporate memory of its activities and be accountable to its citizens or to those it serves (Kanzi, 2010). The study stressed again that record management policies must guarantee that the record management policies are executed in such a way that all individuals in an organisation are acquainted with them.

The policies ought to be reviewed regularly to suit the rising record patterns in organisations. Fitsimmons (2011) concluded that a records management policy assists different people in making informed choices as well as getting access to documents. Mampe and Kalusopa (2012) indicated that for effective management of records, there should be procedures, policies and standards put in place to govern the successful management of documents. These policies and procedures serve as guidelines for the management of records in organisations and they should cover both electronic and paper-based documents.

\section{Challenges in Managing Students' Records}

The increasing volume of students' documents has challenging implications on how to manage these records for efficient delivery of services in an academic institution. For instance, difficulty in getting access to documents, inadequate storage facilities, lack of security, and safety of materials remained a significant challenge in some academic institutions which need to be addressed. Tagbotor et al. (2015) enumerated some challenges confronting records management as the dearth of records management policies and procedures, absence of qualified staff and inadequate resources to implement systems based on legislative requirements. In the view of Attwood and Gill (2008), the majority of administrative heads of academic institutions lament the inadequate financial support and inadequate resources for records keeping in their institutions. Paper documents keep on increasing in volumes daily and it is, therefore, essential for institutions to get rid of some copies and other irrelevant records to create space for relevant documents (Cowling, 2013). Lyaruu (2005) stated that the lack of qualified personnel to handle records management is one of the fundamental challenges confronting the majority 
of registries in most institutions in Tanzania. Popoola and Oluwole (2007) opined that Nigerian university administrators are often concerned about the degree of misplacement or loss of relevant information and the slow pace at which vital information is retrieved from their storage facility when needed. According to Bakkabulindi and Muhenda (2008), despite the value of information for the operation of an organisation, records in many developing countries are characterised by poor management, inefficient filing, poor storage, and irregular disposition.

Davis (2007) and Fasasi (2010) confirmed in their studies that records keeping in some institutions are poorly done. They show that majority of the institutions in Akwa Ibom State have not been able to embrace the information management system to improve their administrative tasks. Otuama (2010) pointed out that lack of archival repositories, lack of funds, lack of storage facilities, and the absence of records management policies hindered proper record management.

\section{Methodology}

The study was a qualitative one and based on a case study design. The qualitative approach was adopted because it allows the researcher to obtain first-hand information from the participants about a phenomenon or problems in their natural settings or environment. According to Creswell (2012), qualitative research is used to explore and understand social or human problems of any individual or group. The population for the study comprised of all senior staff and senior members at the Admissions and Records offices of GCTU. An interview guide was the only instrument used to collect data for the study. The entire population of nine (9) staff was used for the study because this number was very small and could be managed within this study. This included four (4) females and five (5) males, out of this there were two (2) senior members who were the heads of the departments. The other seven (7) were all senior staff. The composition of staff by department who participated in the study includes four (4) staff working at the
Records office and five (5) staff working at the Admissions office respectively, because these categories of staff were in the position to provide the necessary information needed for the study. The Qualitative Content Analysis Software (QCAS) Nvivo (20.0 version) was used to analyse the qualitative data based on the themes that emerged from the research objectives. A total of nine (9) interviewees were interviewed including the two heads of department. The researchers designed a semi-structured interview guide to conduct the faceto-face interview. All the interviews were audio recorded by the researchers and later transcribed, coded, and grouped based on emerging themes. Each of the interviews with a participant lasted 30-35 minutes during their convenient hours in their offices. The results for each objective were presented in narrative as well as quotation marks. Five (5) respondents representing $56 \%$ of them had served between $0-5$ years in their current positions, whereas three (3) respondents representing 33\% had worked between $5-10$ years, only one (1) respondent representing $11 \%$ had worked for 11 years.

\section{Discussion of Results}

In the area of gender of the respondents $5(56 \%)$ were male whereas 4 were female (44\%) signifying a slight variation in terms of gender.

\section{Level of Staff Knowledge in Records Management}

The objective one of this study was to ascertain the level of knowledge of respondents in records management. Resp - AO means from Admission office and Resp - RO means from Records office. It was established that none of the respondents had acquired any formal qualifications in records management, however majority of them had learnt on the job.

The following are their responses:

"No, I don't have a professional certificate in records management, but I was given training when I used to work at the Admissions office of the University of Cape Coast. 
It is the knowledge I acquired through that training I had that I have been using to work since I was employed here (Resp 1 - AO)."

Other respondents stated the following:

"Honestly speaking, I never had any knowledge in records management when I started working in this office; however, I am doing my best to provide the best quality of service to my clients without any discrimination (Resp2 - AO)."

This opinion was shared by one of the respondents whose view was expressly carried in the following: Frankly speaking, I did not have any knowledge or experience in records management but with my readiness and preparedness to learn, I have also gained some little experience like my colleague seniors - honestly, the experience I have currently, I acquired it on the job through the day-to-day management of records in the office (Resp3-AO)."

Another respondent from the admissions office had this to say:

"I acquired knowledge in records management in this office through daily practice on how to keep and retrieve records - however, my knowledge is still limited, so I will say that my level of knowledge in records management is inadequate (Resp4 - AO)."

A respondent from the admissions office intimated the following:

"I learnt records management through my work in the Admissions' office, I don't have broad knowledge about records management; I am pleading with the University management to organise periodic workshops, seminars and training for us to gain full knowledge in records management, this will go a long way to help the entire university not only the staff at the admissions office. (Resp 5-AO)

Respondents were, therefore, asked to show the level of knowledge in records management, a respondent from the records office had the following to say:

"I don't have any professional certificate in records management, but I was made to go for a three (3) day training upon assuming office, to help me perform my duties well. I have also learnt on the job. However, these are not enough to deliver good services to clients - I wish to use this opportunity to ask for more training, seminars and workshops (Resp 1 RO)."

This opinion was shared by one of the respondents whose view was also expressed in the following:

"Sir, I have knowledge but not adequate, I learnt it through my duties in the Records office - my senior colleagues are doing a fantastic work in terms of teaching me how to discharge my duties without much challenges, even though they are not professionals (Resp 2 - RO).”

A similar sentiment was expressed by another respondent from the Records office as follows:

"We are all in the same car, I learnt records management on the job - however, I am reading a lot on records management from the internet (Resp 3 - RO)."

"Yes, I did not have any knowledge before coming, so I obtained every experience from here - despite the initial challenges that I encountered as a new staff, I am still learning a lot about records management, I am sure that through determination I will cover a lot and stand firm to work in the days ahead (Resp.4 - RO)."

The findings indicated that none of the respondents has a professional training or certificate in records management. This confirms the study by Manyambula (2009) which established that poor students' records management in some universities was attributed to unqualified staff in most registries with people who do not have basic training or without training in record management occupying certain positions. Many respondents had however, acquired knowledge through the work, from the Internet as well as periodic workshops.

\section{Staff Training on Records Management}

Objective two of the study was to find out if the staff of the Records and Admissions offices have any training in records management. One respondent said that:

"Yes, I had training on records management; however, I must confess that one training alone is not sufficient for me to deliver quality services, I think that we have 
to get regular training if we have to satisfy the needs of our cherished clients (Resp1 - AO)."

When asked whether that training had helped them in their activities, the following were the comments of the respondents:

"My brother, half a loaf is better than none, we are still fighting for similar training. I think that users are expecting quality services from us and the only way we can provide them with good services is through periodic training, seminars, workshops and conferences (Resp2 - AO)."

"Yes, a one day on the job training/workshop, we went through the processes of records management practices organised by the KNUST for affiliate institutions - however, we need more, since one training cannot prepare a staff to discharge his or her duties well

(Resp3-AO)."

An interviewee expressed the following:

"No, I have not been given any refresher course or a workshop or any official training since I started working at the admissions office. Every training I have had is learning on the job; honestly, it is affecting me negatively, I should have been given adequate training by now." (Resp4 - AO)."

This is what a respondent from the Admission office had to say concerning training:

"Yes, I had training from the head of the department to be able to do the work, so it was not intensive, I will say it was an in - service training; since then, I never had any training on my work again which is not good at all (Resp5 - AO)."
The researchers also sought the views of staff from the Records office concerning training on records management. Their views are presented below:

"Yes, I had training in records management. It was a refresher course I received at my former workplace, before joining GCTU (Resp1 - RO)."

A respondent from the records office stated the following:

"Yes, I had training in records management, it was an educative one, I think that management should organise another one for us again since the first one was not enough - it has really helped me a lot (Resp 2 - RO)."

This opinion was shared by one of the respondents whose view was also expressly carried in the following:

"No, I have never been given any formal training in records management apart from the on the job experience I have acquired - it has added some knowledge and quality to my daily activities in the office, I wish another of such training is organised to refresh the staff in this office (Resp $3-\mathrm{RO}) . "$

Another respondent from the Records office had the following to say:

"No, I don't have any formal training in records management, the knowledge I have acquired has been on the job (Resp4 - RO)."

From the findings, it can be deduced that the majority of staff had some form of training, although inadequate. This result contradicts a study by Abdulrahman (2015) which established that staff involved in management of records in the university libraries in North Central Nigeria did not have any kind of training.

\section{Existence of Policy on Record Management}

Policy must be in place to guide and support the management of students' records. The researchers therefore sought to ascertain if the University has a written policy to regulate the management of records in the two departments. The following were the responses of the participants: 
"I am not sure if there is any policy to that effect.... For electronic media, we keep it for a long time and even keep a backup for future reference but with the manual records we keep them for five (5) years after the student has graduated then they are disposed of (Resp1 - AO)."

The following was how a respondent from the Admission office shared his view on the existence of a policy on records management:

"Honestly, there is no policy covering either manual or electronic records......

the admissions office has never had a written records management policy to regulate its records management activities (Resp 2 - AO)."

An interviewee had the following to say with regards to policy on records:

"We have always used a form of some unwritten policy handed down to us by the Head of Admissions. In light of the fact that there is no policy to regulate records management in the University (Resp 3 AO)."

The following sentiment was expressed by a respondent from the Admission office:

"No, the Admissions' office has never had a written records management policy to regulate the records activities. We have always used a form of some unwritten policy handed down to us by the Head of Admissions. As indicated earlier by my boss and colleagues, we don't have any policy that guides all record management activities in this department (Resp 4 - AO)."

A similar expression was made by another respondent from the Admissions office:

"Honestly, we need a comprehensive policy on records management - this policy will help our daily activities, and also guide us on which material to retain and those to dispose of; with the existence of the policy, we will not also go astray in the discharge of our duties (Resp 5 - AO)."

Other respondents in the Records Office said the following:
"No, there has never been any policy anywhere in any document in this University to that effect...He continued that there is no regulatory framework that regulates records management practices in the University (Resp1 - RO)."

One respondent in the Records office had this to say: "We keep the manual records for a period of time before disposing of them but the electronic records are kept forever ... this practice is not guided by any policy (Resp2 - RO)."

The following opinion was shared by one of the respondents from the records office:

"I think my colleagues have said it all, we don't have a comprehensive policy for any form of records, which is very bad for this institution (Resp3 - RO)."

An interviewee expressed the following:

"No, the Records office has never had any written records management policy to guide its activities. We only follow the instructions of our boss to carry out our activities in this office, therefore all the follow-up questions are not applicable (Resp 4 RO)."

These findings do not support the study of Tagbotor et al. (2015) which revealed the existence of comprehensive records management policies and manual in a Nigerian Polytechnic. However, the findings support Otu et al. (2014) that the Koforidua Technical University had no laid down records management policy and had a weak programme structure for managing records.

\section{Challenges in Managing Students' Records}

The interviews disclosed some challenges with students' records that confronted staff with regard to their duties. Their responses show the various challenges they go through as follows:

"We have a few challenges when it comes to records management. The major ones are inadequate resources, lack of storage space and lack of adequate staff - we have been complaining about inadequate space, yet nothing has been done about it, so we have also stopped the fight (Resp1 - AO)". 
Another interviewee also bemoaned the lack of accurate information needed from students' and inadequate space in the Admissions office. The following was how a respondent expressed his frustration:

"Yes, we face a lot of challenges in our work. Some of the challenges are, first, some of the students don't provide all the information needed to make the records complete and this causes a lot of frustration. Secondly, we don't have enough storage space and resources like files and cabinet for our work (Resp2 - AO)".

Similar sentiments were expressed by another respondent:

"Yes, we have many challenges some of which are, the students not submitting all the documents required for their application to be completed on time. Because of this, sometimes several calls have to be made to students, which is very frustrating. Resources to work are also inadequate (Resp3 AO)".

Interestingly, another respondent from the Admissions office had the following to say:

"Well in my view, I think, we should consider digitization as a new way of creating space for incoming records since the world is tilting towards electronic means of doing things (Resp 4 - AO)."

"Yes, we have numerous challenges, some of which are inadequate storage space, already used results checker for which reason one has to call students several times before a new one is brought, inadequate working resources (Resp5 - AO)".

The sentiments expressed were not different from those from Admissions office - a respondent from the Records office said the following:

"Some of the challenges we face in the records department are, lack of storage space, limited number of staff, inadequate storage equipment like cabinet, lack of training, inadequate office space and lack of policy to guide records management. These have impeded the proper management of student records in the department (Resp1 - RO)."
Another respondent from the Records office stated that:

"Yes, we have many challenges some of which are inadequate number of staff for which reason the work is so much on the few staff members at the department, inadequate storage facilities, inadequate and non-existent equipment/resources like overalls, gloves and nose masks. There has never been any training since we started working here and this has seriously impeded our work (Resp 2 - RO)."

"In fact, apart from the limited space for storage, the department also lacks modern facilities such as fire proof cabinet, coupled with insufficient fire equipment (Resp3 - RO). "'

Respondents had various opinions on challenges confronting them in their effort to deliver quality services to their clients. With regards to challenges, a respondent did not mince words as she honestly stated that:

"Yes, we have a lot of challenges. There is inadequate space for hardcopy storage. In the case of storage of soft copy documents, the computers we use are old and not in good condition for storage as they always break down... When there was a change of software in using to work on students' grades, there were so many problems migrating from the old to new for which reason many of student grades cannot be found in the new software. Many of these grades were lost which has created a lot of problems when the affected students request a transcript. Another problem with the migration is also differences in grades and levels of students. Sometimes a student gets an A in a course but you go into the system and the grade there is a $C$. Sometimes too a student may be in level 400 but the records in the system may indicate he is in level 200. All these cause a lot of confusion and it is very frustrating." (Resp4 - RO)

This finding is in line with Bakkabulindi and Muhenda (2008) whose study established that most developing countries are characterised by poor 
management, inefficient filing, poor storage, and irregular disposition.

\section{Conclusion}

The research set out to investigate records management practices in the Admissions and Records departments of the GCTU. It was found that just like many other institutions in Ghana, GCTU does not have policies to regulate the management of records neither do they have adequate resources such as qualified personnel, adequate equipment, space to store the records, and even the needed training for the staff to work effectively. It was also found that because of the inadequate resources to manage student records, the work is impeded greatly especially at the Records office. Notwithstanding the numerous challenges that the staff involved in records management face in the course of their work, they put in the maximum effort to meet the needs of students even though under strenuous conditions.

\section{Recommendations}

Based on the outcomes of this study, the following are recommended to improve student records management at GCTU.

- There is a need for the University to employ a professional Archivist to manage student records.

- There should be a written policy to guide records management in the Admissions office to indicate the records' life cycle.

- The staff at the admissions and records departments should be given formal training or at least refresher courses on a regular basis for the effective performance of their duties.

- There should be adequate resources like bigger office and storage space, computers, printers, scanners, gloves, nose masks, ladder and cabinets and above all human resources for effective records management.

- The University should invest in an electronic record-keeping system since the trend now is digitization. This will save the University a great deal of the troubles the staff go through with the management of student records.

- Good and appropriate software should be acquired for the management of students' records.

\section{References}

Abdulrahman, A. B. (2015). Management of University records for effective administration of Universities in North Central Nigeria. International Journal of Library and Information Science, 7(3): 4754.

Adu-Oppong, A. A. \& Asante, O. (2014). An examination of records management at the College of Technology Education, Kumasi. International Journal of Educational Development, 2(14): 171-183.

Atulomah, B. C. (2011). Perceived records management practice and decision making among university administrators in Nigeria. Library Philosophy and Practice. Retrieved from http://www ://unllib.uni.edu/LPP/.

Attwood, R. \& Gill, J. (2008). Student numbers are at risk as UK demographics shift. Times Higher Education. Retrieved from: http://www.timeshighereducation.co.uk/stor y. asp?storycode $=406$.

Azameti, M. S. K. \& Adjei, E. (2014a). Conceptualization of Policy Challenges in Academic Records Management Strategies in Tertiary Institutions in Ghana. Journal of Education and Literature, 1(3): 91-98.

Azameti, M. S. K. \& Adjei, E. (2013b). Challenges in Academic Records Management in Tertiary Institutions in Ghana. International Journal of Scientific Research in Education, 6(3);287-296.

Bakkabulindi, C. \& Muhenda, M. B. (2008). Good Governance, Records Management, and Ghost Workers in the Ugandan Public Service. Detecting loopholes and identifying inefficiencies in the Ministry of Education and Sports. Paper presented at the 
International Association of Administrative Sciences, Kampala, 14-18 July.

Cowling, C. (2013). Records management manual. University of London.

Creswell, J. W. (2012). Research design: Qualitative, quantitative, and mixed methods. Sage.

Davis, P. (2007). School record system and educational administration in colleges. Pan Book Ltd.

Dikopoulou, A. \& Mihiotis, A. (2012). The contribution of Records Management to Good Governance. The Total Quality Management Journal, 24(2): 123-141.

Egwunyenga, E. J. (2005). Essentials of School Administration. Justice Jeco Publishers.

Fasasi, O. (2010). School record and effective administration. Educational Journal, 2, 3341.

Fitsimmons, G. (2011). The policy/procedure manual part I: making and abiding by good policies. The Bottom Line, 24(4): 233 - 235.

Gama, U. G. (2010). A survey of records management practices in circular primary schools in the Metropolitan Local Government Area (MLGAs) of Kano State. Samaru Journal of Information Studies, 10 (1 \& 2): 23-30.

Ifedili, C. J. \& Agbaire, J. T. (2011). Management of educational records in Nigeria Universities records in Nigeria universities for better results. Review of European studies, 3 (2), 52-57.

ISO 15489 (2001) Information and Documentation - Records Management - Part 1: general, International Standards Organisation. ISO, Geneva.

Iwhiwhu, E, B. (2005). Management of Records in Nigerian Universities: Problems and Prospects. The Journal of Electronic Library, 23(3): 345-355.
Kanzi, N. (2010). An investigation of the role of records management with specific reference to Amathole District Municipality [Unpublished master's thesis]. Nelson Mandela Metropolitan University.

Lyaruu, T. (2005). Personnel records management in the public sector and its impact on the payment of pension: A case study of selected ministries and government agencies [MA Thesis]. University of Dar es Salaam.

Mampe, G. \& Kalusopa, T. (2012). Records management and service delivery: the case of Department of Corporate Services in the Ministry of Health in Botswana. Journal of the South African Society of Archivists, 45: $1-23$.

Manyambula, M. (2009). Public service reform, accountability, and records management: a case study of Tanzania. ESARBICA Journal, 28: 20 -35.

Mensah, M. \& Adams, M. (2014). The nexus between Corporate Governance and Records Management in Private and Public Hospitals in Ghana. Records Management Journal, 24(1): 32-55.

Ololube, N. P. (2013). Educational Management, Planning and Supervision: Model for Effective Implementation. Spring Field Publishers.

Otu, B. O., Bempah, O. \& Amoakohene, K. (2014). Management of students' records at Koforidua Polytechnic: Implications for good governance. Information and Knowledge Management, 4(11): 69-74.

Otuama, S. (2010). Problems faced in Archives and Records Management in Kenya. Retrieved from http://www.informationscienceblog.blogspo t.com/2010/06/problems-faced-in-archives andrecords.html

Popoola, S. O. \& Oluwole, D. A. (2007). Career commitment among records management personnel in a state civil service in Nigeria. 
Records Management Journal, 17(2): 107 116.

Tagbotor, D. P., Adzido, R. Y. N., \& Agbanu, P. G. (2015). Analysis of Records Management and Organisational Performance. International Journal of Academic Research in Accounting, Finance and Management Sciences, 5(2): 1-16.

Tsabedze, V., Mutula, S. M. \& Jacobs, D. (2012). Records Management in the Government of
Swaziland. ESARBICA Journal: Journal of the Eastern and Southern Africa Regional Branch of the International Council on Archives, 31, 47-61.

Wamukoya, J. (2000). Records and archives as a basis for good government: implications and challenges for records managers and archivists in Africa. Records Management Journal, 10(1): 23-33. 